\title{
Diallel analysis of yield, popping expansion, and southern rust resistance in popcorn lines ${ }^{1}$
}

\author{
Análise dialélica da produtividade, capacidade de expansão e resistência à ferrugem- \\ polissora em linhagens de milho-pipoca
}

\author{
Rafael Augusto Vieira ${ }^{2 *}$, Carlos Alberto Scapim ${ }^{3}$, Dauri José Tessmann ${ }^{3}$ e Fernando Teruhiko Hata ${ }^{3}$
}

\begin{abstract}
Ten popcorn inbred lines were crossed in a circulant partial diallel matching scheme (group of lines derived from IAC $112 \times$ group of lines from 'Zaeli'). The hybrids were evaluated in respect to grain yield (GY), popping expansion (PE), and resistance to southern rust (Puccinia polysora, Pp), in randomized block design, with three replications. Data was examined by analyses of variance and Kempthorne and Curnow's diallel analysis. General combining ability (GCA) was significant $(\mathrm{p}<0.10)$ in the set 2 -Zaeli for GY, PE, and partial resistance to Pp. This indicated that additive gene effects are predominant, and therefore breeding methods of recurrent selection are recommended. However, none of lines had outstanding GCA for GY and PE. The line $\mathrm{P}_{8.5}$ was recommended to form breeding populations for resistance to Pp. Specific combining ability (SCA) was detected for GY. The $\mathrm{P}_{9.24} \times \mathrm{P}_{8.6}$ might be promising for GY, if exploited using interpopulational breeding methods.
\end{abstract}

Key words - Zea mays. General and specific combining ability. Puccinia polysora. Plant breeding.

\begin{abstract}
Resumo - Dez linhagens de milho-pipoca (grupo de linhagens IAC $112 \times$ grupo de linhagens 'Zaeli') foram cruzadas em esquema dialélico parcial circulante. Os híbridos foram avaliados quanto ao rendimento de grãos (RG), capacidade de expansão (CE) e resistência parcial à ferrugem-polissora (Puccinia polysora Pp), em delineamento de blocos completos com tratamentos ao acaso, com três repetições. As características foram utilizadas para análises de variância e dialélicas de Kempthorne e Curnow. A capacidade geral de combinação (CGC) foi significante $(\mathrm{p}<0,10)$ no grupo Zaeli para RG, CE e resistência à Pp. Isto indicou a predominância de genes aditivos, e que métodos de seleção recorrente são recomendados para estas características. Não foram encontradas linhagens com CGC favoráveis para RG e CE. A linhagem $\mathrm{P}_{8.5}$ foi recomendada para integrar populações para melhoramento visando resistência à Pp. A capacidade específica de combinação somente foi detectada para RG. O híbrido $\mathrm{P}_{9.24} \times \mathrm{P}_{8.6}$ pode ser promissor para RG se explorando usando métodos intrapopulacionais de melhoramento.
\end{abstract}

Palavras-chave - Zea mays. Capacidades geral e específica de combinação. Puccinia polysora. Melhoramento vegetal.

\footnotetext{
* Autor para correspondência

${ }^{1}$ Recebido para publicação em 09/06/2010; aprovado em 25/04/2011

Financiamento via CNPq - National Counsel of Technological and Scientific Development, Brazil and Araucaria Foundation

${ }^{2}$ Universidade Estadual de Maringá, Maringá-PR, Brasil, rfavieira@msn.com

${ }^{3}$ Universidade Estadual de Maringá, Maringá-PR, Brasil, cascapim@uem.br, djtessmann@uem.br, prox_fdinhu@hotmail.com
} 


\section{Introduction}

Popcorn and other specialty maize are producing value-added properties to the grains in Brazil. Despite the important growth in the consumption of popcorn, diverse studies of the Ministry of Agriculture have determined that production is still limited with regards to the potential market (ARNHOLD et al., 2009; VIEIRA et al., 2009a). However, this situation is being reverted by important advances achieved in the breeding programs (ARNHOLD et al., 2009; SANTOS et al., 2008; SCAPIM et al., 2010; SILVA et al., 2009; TRINDADE et al., 2010; VIEIRA et al., 2009a).

To obtain superior lines and hybrids is one of the major strategies in popcorn breeding programmes for development of high-yielding and popping expansion cultivars. Both additive and nonadditive gene effects are exploited during populations improvement and development of inbred lines. The relative importance of additive and nonadditive effects on total genetic variance is fundamental. This defines which intrapopulational or interpopulational methods are most advantageous.

The genetic potential of maize lines and hybrids has been studied since Jones (1918) suggested the commercial use of double-crosses hybrids. In order to evaluate genotypes, the diallels crosses and top-crosses are useful. Diallels provides information on combining ability and gene effects, and constitute a valuable tool for maize breeders. Nevertheless, the evaluation of diallels crosses among inbred lines are recent and incipient in popcorn germplasm (LARISH; BREWBAKER, 1999; PINTO et al., 2007a, 2007b; VIEIRA et al., 2009b).

The southern rust is caused by Puccinia polysora Underw., and well-adapted to high and low lands in Brazil, and other tropical and sub-tropical environments where maize grown (SHURTLEFF, 1992). This rust has affect leaves causing yield losses up to 50\% (CASTELLANOS et al. 1998; RODRIGUES-ARNON et al., 1980). The partial resistance to southern rust, or slow-rusting, consists of the ability to decrease the disease rates of development, usually by small lesions and less sporulation (ZUMMO, 1988). Since the area under the disease progress curve (AUDPC) measures the disease development over a period, this criteria is commonly to assess partial resistance levels under field conditions.

To prevent yield losses, the development of genotypes with genetic resistance to diseases is a major strategy in maize breeding (VIEIRA et al., 2009b). In fact, the flint germplasm available to popcorn breeding is narrow and does not performed as well as common maize. Consequently, it provides poorer agronomic traits including diseases susceptibility (ZIEGLER; ASHMAN, 1994).
In the present study, the combining ability of popcorn inbred lines was evaluated in circulant partial diallel matching scheme for grain yield, popping expansion, and partial resistance to southern rust (Puccinia polysora, Pp). This study intended to measure the breeding possibilities using this germplasm, and firstly reports the inheritance pattern for the resistance to $\mathrm{Pp}$ in popcorn germplasm.

\section{Material and methods}

Two sets of popcorn lines were crossed in circulant partial diallel matching scheme, with three hybrid combinations per line. The sets were: i) set 1-IAC112: five $S_{8}$ inbred lines, derived from self-pollinations of the hybrid IAC 112, a cultivar with temperate and tropical genealogy; and, ii) set 2-Zaeli: five $\mathrm{S}_{8}$ inbred lines, derived from self-pollinations of the 'Zaeli', a unknown genetic material but with temperate genealogy. The fifteen hybrids were obtained and evaluated in randomized block design, with three replications, in Maringá, PR, Brazil (23⒉' South latitude, $52^{\circ} 04^{\prime}$ 'West longitude and $510 \mathrm{~m}$ altitude), during the 2007/08 cropping season. One check hybrid (single hybrid IAC 112, moderately susceptible to Pp) was included, and its mean was compare to diallel crosses. In order to study the diallel crosses, the check hybrid was not included in statistical analyses.

The experimental plots consisted of a $5 \mathrm{~m}$ long row with 25 plants and spaced $0.9 \mathrm{~m}$ apart. Plots were fertilized with $20 \mathrm{~kg} \mathrm{ha}^{-1} \mathrm{~N}, 50 \mathrm{~kg} \mathrm{ha}^{-1} \mathrm{P}_{2} \mathrm{O}_{5}$, and $50 \mathrm{~kg} \mathrm{ha}^{-1}$ $\mathrm{K}_{2} \mathrm{O}$ at sowing, and $100 \mathrm{~kg} \mathrm{ha}^{-1} \mathrm{~N}$ sidedressing, when the plants reached development stage $\mathrm{V}_{4}$. Cultural treatments were based on the crop requirements; however, fungicide applications were not performed. The Pp severity was evaluated under natural infestations on hybrids. The ear leaf and the first leaves below and above of five plants were sampled and evaluated per plot. Three evaluations were carried out approximately every 12 days, after 15 days of flowering. Severity data was used to calculate the area under the disease progress curve (AUDPC), as proposed by Campbell and Madden (1990).

The ears were hand-harvested and threshed each plot, and grain yield data was obtained and corrected to $15 \%$ moisture. Next, data was corrected by number of plants per plot, as according to Schmildt et al. (2001), and transformed to $\mathrm{kg} \mathrm{ha}^{-1}$. Popping expansion was evaluated in a sample of $30.0 \mathrm{~g}$ of grains that were popped in a automatic machine developed by Embrapa-CNPDIA, at $237{ }^{\circ} \mathrm{C}$ during $120 \mathrm{~s}$. Grains popped were collected from central region of ears, of which had storage until $14 \%$ moisture was reached.The popped volume was measured using a beaker of $2,000 \mathrm{~mL}$ capacibility. 
Grain yield, popping expansion, AUDPC values for southern rust, and the southern rust severity in the last evaluation (at 92 days after sowing) were used in the statistical analyses. Bartlett's test was applied to verify the homogeneity of variances. The method of KolmogorovSmirnov was used verify the normal distribution of errors. Since the parametric assumptions were satisfied data transformations were not necessary.

Two-way analyses of variance were carried out. Next, the means of traits were used to perform the partial circulant diallel analysis, as Kempthorne and Curnow (1961). The statistic model was:

$$
Y_{i j}=\mu+g_{i}+g_{j}+s_{i j}+\varepsilon_{i j}
$$

in which,

$\mu$ : overall mean;

$g_{i}$ and $g_{j}$ : effects of general combing ability (GCA) associated to the lines $i$ (set 1-IAC 112) and $j$ (set 2Zaeli);

$s_{i j}$ : effect of specific combining ability (SCA) to the combination of the lines $i$ and $j$;

and $\varepsilon_{i j}$ : mean experimental error to the combination $i j$. The mean square errors and degrees of freedom from analysis of variance also were included in diallel analyses.

The percentages of sum of squares from GCA and SCA were calculated as follows: i) Percentage of sum of squares from $\mathrm{GCA}$ : $\% \mathrm{SSG}=\mathrm{SSG} / \mathrm{SSG}+$ SSS x 100, in which SSG: sum of squares from GCA and SSS: sum of squares from SCA; ii) Percentage of sum of squares from SCA: $\% \mathrm{SSS}=\% \mathrm{SSG}-100$, in which \%SSG: percentage of sum of squares from GCA. Random effects of genotypes were considered for the analyses. Data analyses were carried out using the program Genes (Universidade Federal de Viçosa, Viçosa, MG).

\section{Results and discussion}

Mean grain yield (GY) was from 3,200.8 $\left(\mathrm{P}_{9.27} \times\right.$ $\mathrm{P}_{8.4}$ ) to $1,745.7 \mathrm{~kg} \mathrm{ha}^{-1}$ among diallel crosses (TAB. 1). For popping expansion (PE), the mean values was from $33.4\left(\mathrm{P}_{9.27} \times \mathrm{P}_{8.4}\right)$ to $15.4 \mathrm{~mL} \mathrm{~g}^{-1}$. Considering the means for the check hybrid IAC $112\left(3,175.9 \mathrm{Kg} \mathrm{ha}^{-1}\right.$ for GY and $32.4 \mathrm{~mL} \mathrm{~g}^{-1}$ to PE (TAB. 1), the hybrid combination $\mathrm{P}_{9.27} \times \mathrm{P}_{8.4}$ was considered outstanding. It suggested that lines $\mathrm{P}_{9.27}$ (set 1-IAC 112) and $\mathrm{P}_{8.4}$ (set 2-Zaeli) may be promising per se, or their combination resulted in positive heterosis and favorable allelic complementation.
Regarding to the partial resistance to southern rust, the hybrids ranged from $10.4\left(\mathrm{P}_{9.24} \times \mathrm{P}_{8.5}\right)$ to $24.4 \%\left(\mathrm{P}_{9.20} \times\right.$ $\left.\mathrm{P}_{8.6}\right)$ in severity at 92 days, and from $57.9\left(\mathrm{P}_{9.22} \times \mathrm{P}_{8.2}\right)$ to 191.4 $\left(\mathrm{P}_{9.20} \times \mathrm{P}_{8.6}\right)$ in AUDPC (TAB. 1). When compared to check IAC 112, the means of hybrids corresponds to moderately susceptible to susceptible popcorn cultivars. This revealed some possibilities with regards to the improvement of partial resistance to southern rust using this germplasm, especially if additive genes would be acting. Mean values for hybrid combinations per line are presented in the Table 1 . In this sense, it was possible to emphasize the lines $\mathrm{P}_{8.5}$ and $\mathrm{P}_{8.2}$ from set 2-Zaeli to $\mathrm{Pp}$ resistance.

Hybrid effects were significant $(\mathrm{p}<0.10)$ for $\mathrm{GY}$ and AUDPC (TAB. 2). It indicated that some hybrids were superior for GY, and it is possible to identify lines which were combined in outstanding hybrids. Concerning to AUDPC, which integrates the Pp evaluations, some hybrids were able to reduce the disease development over the season, and therefore they had higher levels of partial resistance. This is a favorable condition for plant breeding. Hybrid effects were not detected $(p>0.10)$ for $\mathrm{PE}$ and severity at $92 \mathrm{~d}$ (TAB. 2).

General combining ability was significant $(\mathrm{p}<0.10)$ for GY, PE, and partial resistance to $\mathrm{Pp}$ in the inbred lines from set 2-Zaeli (TAB. 2). Therefore, it is possible to assume that additive gene effects are important for these traits, and suggests that alleles from some lines are outstanding compared to the other ones. Specific combining ability - from nonadditive gene effects from dominance or epistasis - was detected for GY $(p<0.10)$. This indicated that some hybrids are heterotic and had good allelic complementation.

For $\mathrm{PE}$ and partial resistance to $\mathrm{Pp}$, the relative importance of general combining ability was higher than the importance of specific combining ability (TAB. 2). This indicates that additive genetic variability had larger breeding possibilities than nonadditive variability, and therefore the intrapopulational breeding based on recurrent selection are recommendable.

The estimates of general combining ability effects $\left(\hat{g}_{j}\right)$ for the lines of set 2-Zaeli are presented at Table 3. For GY and PE, positive $\hat{g}_{j}^{\text {'s }}$ larger than its standard deviation (SD) was considered relevant. For partial resistance to $\mathrm{Pp}$, negative $\hat{g}_{j}^{\text {'s }}$ larger than its SD was relevant. None of lines had favorable $\hat{g}_{j}$ in respect to $\mathrm{GY}$ and PE. The lines $\mathrm{P}_{8.1}$ (for GY) and $\mathrm{P}_{8.2}$ (for PE) had negative relevant $\hat{g}_{j}$, and might reduce GY in their hybrids. In fact, since none of other lines had relevant $\hat{g}_{j}$, it denoted that lines from set 2Zaeli are quite similar concerning its genetic frequencies. This also occurred for lines from set 1-IAC 112 ( $p>0.10$ for general combining ability). Therefore, it ratified that self-pollination of commercial hybrids are not appropriate 
Table 1 - Means for grain yield ${ }^{\mathrm{a}}\left(\mathrm{kg} \mathrm{ha}^{-1}\right)$, popping expansion ${ }^{\mathrm{b}}\left(\mathrm{mL} \mathrm{g}^{-1}\right)$, southern rust severity at 92 days after sowing $(\%)$, and area under the disease progress curve ${ }^{\mathrm{d}}$ (AUDPC) in diallel crosses obtained by circulant partial scheme

\begin{tabular}{|c|c|c|c|c|c|c|}
\hline \multirow{2}{*}{ Inbred lines } & \multicolumn{5}{|c|}{ Set 2-Zaeli } & \multirow[t]{2}{*}{ Mean $^{1}$} \\
\hline & $1^{\prime}\left(\mathrm{P}_{8.5}\right)$ & $2^{\prime}\left(\mathrm{P}_{8.2}\right)$ & $3^{\prime}\left(\mathrm{P}_{8.4}\right)$ & $4^{\prime}\left(\mathrm{P}_{8.1}\right)$ & $5^{\prime}\left(\mathrm{P}_{8.6}\right)$ & \\
\hline \multicolumn{7}{|l|}{ Set 1-IAC112 } \\
\hline \multirow{4}{*}{$1\left(\mathrm{P}_{9.22}\right)$} & $2,697.5 \mathrm{a}$ & $2,453.7$ & $2,688.5$ & & & $2,613.2$ \\
\hline & $23.4 \mathrm{~b}$ & 19.4 & 25.9 & & & 22.9 \\
\hline & $10.7 \mathrm{c}$ & 15.4 & 12.2 & & & 12.8 \\
\hline & $83.5 \mathrm{~d}$ & 57.9 & 93.8 & & & 78.4 \\
\hline \multirow{4}{*}{$2\left(\mathrm{P}_{9.27}\right)$} & & $3,112.0$ & $3,200.8$ & $1,894.4$ & & $2,735.7$ \\
\hline & & 24.4 & 33.4 & 26.3 & & 28.1 \\
\hline & & 10.8 & 19.3 & 19.2 & & 16.5 \\
\hline & & 83.1 & 139.0 & 150.0 & & 124.0 \\
\hline \multirow{4}{*}{$3\left(\mathrm{P}_{9.1}\right)$} & & & $2,299.4$ & $2,457.4$ & $1,936.4$ & $2,231.1$ \\
\hline & & & 26.9 & 27.8 & 25.4 & 26.7 \\
\hline & & & 13.1 & 22.2 & 19.0 & 18.1 \\
\hline & & & 99.1 & 151.9 & 151.2 & 134.1 \\
\hline \multirow{4}{*}{$4\left(\mathrm{P}_{9.24}\right)$} & $2,721.8$ & & & $1,745.7$ & $2,925.5$ & $2,464.3$ \\
\hline & 23.9 & & & 21.1 & 28.2 & 24.4 \\
\hline & 10.4 & & & 21.0 & 19.9 & 17.1 \\
\hline & 85.5 & & & 144.7 & 145.1 & 125.1 \\
\hline \multirow{4}{*}{$5\left(\mathrm{P}_{9.20}\right)$} & $2,931.6$ & $2,724.5$ & & & $2,095.1$ & $2,583.7$ \\
\hline & 24.8 & 15.7 & & & 27.6 & 22.7 \\
\hline & 11.9 & 17.4 & & & 24.2 & 17.8 \\
\hline & 88.7 & 86.0 & & & 191.4 & 122.0 \\
\hline \multirow{4}{*}{ Mean $^{2}$} & $2,783.6$ & $2,763.4$ & $2,729.6$ & $2,032.5$ & $2,319.0$ & \\
\hline & 24.0 & 19.8 & 28.7 & 25.1 & 27.1 & \\
\hline & 11.0 & 14.5 & 14.9 & 20.8 & 21.0 & \\
\hline & 85.9 & 75.6 & 110.7 & 148.9 & 162.5 & \\
\hline \multirow{4}{*}{ Check hybrid (IAC 112) } & \multicolumn{6}{|c|}{$3,175.9$} \\
\hline & \multicolumn{6}{|c|}{32.4} \\
\hline & \multicolumn{6}{|c|}{6.2} \\
\hline & \multicolumn{6}{|c|}{43.03} \\
\hline
\end{tabular}

${ }^{1}$ Means of hybrids combinations per line from set 1-IAC 112. ${ }^{2}$ Means of hybrids combinations per line from set 2-Zaeli

to obtain lines with relative broad genetic base. In our understanding, this meet with expectation since two to four inbred lines are employed to obtain the commercial hybrids. In this instance, three lines are combined in IAC 112 , the base material for the lines of set 1 .

The lines $\mathrm{P}_{8.5}$ and $\mathrm{P}_{8.2}$ were the ones which most contributed to partial resistance to $\mathrm{Pp}$. Due to the relevant negative $\hat{g}_{i}$, these lines decreased the overall mean of diallel, reducing final severity level and Pp progress on their hybrids. Since $\mathrm{P}_{8.2}$ had negative $\hat{g}_{j}$ for $\mathrm{PE}$, only $\mathrm{P}_{8.5}$ was recommended to form breeding populations for partial resistance to $\mathrm{Pp}$.
Regarding to the specific combining ability for GY, two hybrid combinations with outstanding estimates of specific combining ability effects were identified (TAB. 4). These two combinations were $\mathrm{P}_{9.1} \times \mathrm{P}_{8.1}\left(\mathrm{~s}_{\mathrm{ij}}\right.$ $\left.=616.1 \mathrm{~kg} \mathrm{ha}^{-1}\right)$ and $\mathrm{P}_{9.24} \times \mathrm{P}_{8.6}\left(\mathrm{~s}_{\mathrm{ij}}=490.5 \mathrm{~kg} \mathrm{ha}^{-1}\right)$. In conclusion, these combinations overcome its expected performance if considering the general combining ability of their lines. The hybrid combination $\mathrm{P}_{9.1} \times \mathrm{P}_{8.1}$ included $\mathrm{P}_{8.1}$ (with negative $\hat{g}_{j}$ for GY), and therefore was discarded to be exploited by breeding. The hybrid $\mathrm{P}_{9.24} \times \mathrm{P}_{8.6}$, however, is promising for interpopulational breeding for GY. 
Table 2 - Analyses of variance and circulant partial diallel analyses of Kempthore and Curnow (1961) for grain yield (GY, kg ha $\left.{ }^{-1}\right)$, popping expansion (PE, $\mathrm{mL} \mathrm{g}^{-1}$ ), southern rust severity at 92 days after sowing (Sev92), and area under the disease progress curve (AUDPC)

\begin{tabular}{|c|c|c|c|c|c|}
\hline \multirow{2}{*}{ Sources of variation } & \multirow{2}{*}{ DF } & \multicolumn{4}{|c|}{ Mean squares } \\
\hline & & GY & $\mathrm{PE}$ & sev92 & AUDPC \\
\hline Hybrids & 14 & $612580.6^{*}$ & $51.4^{\mathrm{ns}}$ & $64.3^{\mathrm{ns}}$ & $4374.3^{*}$ \\
\hline General combining ability (GCA) set 1-IAC 112 & 4 & $146521.8^{\mathrm{ns}}$ & $46.1^{\mathrm{ns}}$ & $8.7^{\mathrm{ns}}$ & $950.4^{\mathrm{ns}}$ \\
\hline General combining ability (GCA) set 2-Zaeli & 4 & $1104627.7^{*}$ & $101.3^{*}$ & $180.6^{*}$ & $13536.9^{*}$ \\
\hline Specific combining ability (SCA) & 6 & $595295.0^{*}$ & $21.1^{\mathrm{ns}}$ & $24.6^{\mathrm{ns}}$ & $556.2^{\mathrm{ns}}$ \\
\hline Blocks & 2 & $202948.0^{\text {ns }}$ & $15.3^{\text {ns }}$ & $784.7^{*}$ & $22343.1^{*}$ \\
\hline Error & 28 & 204218.9 & 38.2 & 38.7 & 2249.3 \\
\hline Overall mean & & 2525.6 & 24.9 & 16.4 & 116.7 \\
\hline Coefficient of variation & & 17.9 & 24.8 & 37.8 & 40.6 \\
\hline \%SS GCA set 1-IAC112 & & 7 & 26 & 4 & 6 \\
\hline \%SS GCA set 2-Zaeli & & 52 & 57 & 80 & 88 \\
\hline \%SS SCA & & 42 & 18 & 16 & 5 \\
\hline
\end{tabular}

SS: Sum of squares. ${ }^{*} p<0.10$ by F-test. ${ }^{n s} p>0.10$ by F-test

Table 3 - Estimates of general combining ability effects in the lines of set 2-Zaeli $\left(\hat{g}_{j}\right)$ for grain yield (GY, $\mathrm{kg}$ ha $\left.{ }^{-1}\right)$, popping expansion $\left(\mathrm{PE}, \mathrm{mL} \mathrm{g}^{-1}\right)$, southern rust severity at 92 days after sowing (Sev92), and area under the disease progress curve (AUDPC)

\begin{tabular}{ccccc}
\hline \multirow{2}{*}{ Inbred lines } & \multicolumn{3}{c}{$\hat{g}_{j}$} \\
\cline { 2 - 5 } & $\mathrm{GY}$ & $\mathrm{PE}$ & $\mathrm{Sev92}$ & AUDPC \\
\hline$n^{\prime}\left(\mathrm{P}_{8.5}\right)$ & 302.8 & 0.5 & $\mathbf{- 6 . 1}$ & -29.1 \\
2' $\left(\mathrm{P}_{8.2}\right)$ & 226.8 & $\mathbf{- 5 . 6}$ & -2.4 & $\mathbf{- 4 6 . 5}$ \\
3' $\left(\mathrm{P}_{8.4}\right)$ & 212.4 & 2.8 & -0.8 & 3.9 \\
4' $\left(\mathrm{P}_{8.1}\right)$ & $\mathbf{- 5 6 6 . 3}$ & -0.8 & 5.1 & 33.2 \\
5' $\left(\mathrm{P}_{8.6}\right)$ & -175.7 & 3.1 & 4.2 & 46.2 \\
\hline SD $\hat{g}_{j}-\hat{g}_{j}^{\prime}$ & 367.4 & 3.5 & 4.7 & 39.6 \\
\hline
\end{tabular}

SD: Standard deviation. Relevant estimates are highlighted in bold

Table 4 - Estimates of specific combining ability effects $\left(\mathrm{s}_{\mathrm{ij}}\right)$ between lines of the two sets for grain yield $\left(\mathrm{GY}, \mathrm{kg} \mathrm{ha}^{-1}\right)$

\begin{tabular}{|c|c|c|c|c|c|}
\hline \multirow{2}{*}{ Inbred lines } & \multicolumn{5}{|c|}{ Set 2-Zaeli } \\
\hline & $1^{\prime}\left(\mathrm{P}_{8.5}\right)$ & $2^{\prime}\left(\mathrm{P}_{8.2}\right)$ & $3^{\prime}\left(\mathrm{P}_{8.4}\right)$ & $4^{\prime}\left(\mathrm{P}_{8.1}\right)$ & $5^{\prime}\left(\mathrm{P}_{8.6}\right)$ \\
\hline \multicolumn{6}{|l|}{ Set 1-IAC112 } \\
\hline $1\left(\mathrm{P}_{9.22}\right)$ & 28.8 & -139.0 & 110.2 & & \\
\hline $2\left(\mathrm{P}_{9.27}\right)$ & & 107.1 & 210.33 & -317.4 & \\
\hline $3\left(\mathrm{P}_{9.1}\right)$ & & & -320.64 & 616.1 & -295.5 \\
\hline $4\left(\mathrm{P}_{9.24}\right)$ & -191.8 & & & -298.7 & 490.5 \\
\hline $5\left(\mathrm{P}_{9.20}\right)$ & 163.0 & 31.9 & & & -195.0 \\
\hline
\end{tabular}

Relevant estimates are highlighted in bold 
Both additive and nonadditive gene effects were important for GY. Their relative importance was similar on genetic variability, indicating that the exploitation of both gene effects is appropriate using recurrent reciprocal selection. In this context, to improve many breeding populations simultaneously are recommended before obtaining lines. In this manner, high-yielding, vigorous, and heterotic lines are supposed to be obtained. This strategy was supported by results from Scapim et al. (2002) and Simon et al. (2004), which found smaller inbreeding depression in improved populations. In fact, this strategy also seems to be appropriate to obtain popcorn genotypes with resistance to northern leaf blight hybrids (VIEIRA et al., 2009c). Since inbreeding depression levels are low for PE (SIMON et al., 2004), these improved populations should have genetic variability and high PE levels (superior than $28 \mathrm{~g} \mathrm{~mL}^{-1}$ ).

When a trait is major conditioned by additive genes and heterotic effects are not strongly important, either phenotypic or genotypic means among parents are a good predictor of hybrids' performance, and screening or evaluating lines per se is crucial for maize breeding programmes. In this sense, both PE and Pp are included.

Additive gene effects have been more important than nonadditive effects for PE in landraces and open-pollinated popcorn varieties from South American germplasm, in South and Central Brazil (ANDRADE et al., 2002; FREITAS JÚNIOR et al., 2006; MIRANDA et al., 2008; PINTO et al., 2007; SCAPIM et al., 2002; VIEIRA et al., 2009a). For popcorn inbred lines, these predominance was reported by Larish and Brewbaker (1999) in U.S. germplasm, and Pinto et al. (2007a, 2007b), in Brazilian adapted germplasm. Our study corroborated with other studies and reinforces findings previously obtained.

Concerning to the partial resistance to $\mathrm{Pp}$, no studies were reported previously in popcorn germplasm worldwide. The predominance of additive genes conditioning this trait was found in common corn (SILVA et al. 2001). Slow-rusting resistance was also found in commom maize (BRUNELLI et al., 2004; CHÁVEZMEDINA et al., 2007). Nonadditive gene effects, however, were also reported (JINES et al., 2006; SILVA et al., 2001). In popcorn germplasm, Vieira et al. (2009b) reported the major importance of additive genes for partial resistance to northern leaf blight (Exserohilum turcicum) and gray leaf spot (Cercospora spp.) in popcorn inbred lines. For resistance to $\mathrm{Pp}$ in popcorn, this study firstly reported the major action of additive gene effects. Concerning this study, it was possible to affirm that the inheritance of slow-rusting resistance to $\mathrm{Pp}$ (partial resistance) was from additive genes. Suitable level of partial resistance provides a durable and no race-specific resistance, and since many races occur simultaneously the partial resistance is a important tool for breeding programmes.

The importance of promising inbred lines with resistance to southern rust resistance is emphasized when considering the significant correlations between yield losses and southern rust severity (CASTELLANOS et al., 1998). In this respect it is believed that popcorn breeding including $\mathrm{P}_{8.5}$ are useful.

\section{Conclusions}

1. General combining ability were more important than specific combining ability for grain yield, popping expansion, and partial resistance to southern rust, indicating that additive gene are predominant, and therefore recurrent selection is recommendable;

2. The inbred line $\mathrm{P}_{8.5}$ is recommended to form breeding populations for partial resistance to southern rust;

3. The hybrid combination $\mathrm{P}_{9.24} \times \mathrm{P}_{8.6}$ was promising for interpopulational breeding for GY.

\section{Acknowledgements}

The authors thank CNPq - National Counsel of Technological and Scientific Development, Brazil; and Araucaria Foundation, from the Parana State Government, Brazil, for partially fund this work.

\section{References}

ANDRADE, R. A. et al. Análise dialélica da capacidade combinatória de variedades de milho-pipoca. Acta Scientiarum. Agronomy, v. 24, n. 05, p. 1197-1204, 2002.

ARNHOLD, E. et al. Evaluation of top-cross popcorn hybrids using mixed linear model methodology. Chilean Journal of Agricultura Research, v. 69, n. 01, p. 46-53, 2009.

BRUNElli, K. R.; SILVA, H. P.; ARANHA, L. E. C. Mapeamento de genes de resistência quantitativa a Puccinia polysora em milho. Fitopatologia Brasileira, v. 27, n. 02, p. 134-140, 2004.

CAMPBELL, C. L.; MADDEN, L. V. Introduction to plant disease epidemiology. New York : John Wiley, 1990. 532 p.

CASTELlanOS, J. S.; HALLAUER, A. R. CORDOVA, H. S. Relative performance of testers to identify elite lines of corn (Zea mays L.) Maydica, v. 43, n. 03, p. 217-226, 1998.

CHÁVES-MEDINA, J. A.; LEYVA-LÓPEZ, N. E.; PATAKY, J. K. Resistance to Puccinia polysora in maize accessions. Plant Disease, v. 91, n. 11, p. 1489-1495, 2007. 
FREITAS JÚNIOR, S. P. et al. Capacidade combinatória em milho-pipoca por meio de dialelo circulante. Pesquisa Agropecuária Brasileira, v. 41, n. 11, p. 1599-1607, 2006.

JINES, M. P. Mapping resistance to southern rust in tropical $\times$ temperate maize recombinant inbred topcross population. Theoretical and Applied Genetics, v. 114, n. 04, p. 659$667,2006$.

JONES, D. F. The effects of inbreeding and crossbreeding upon development. Connecticut: Connecticut Agricultural Experimental Station Bulletin, 1918. 100 p.

KEMPTHORNE, O.; CUNOW, R. N. The partial diallel cross. Biometrics, v. 17, n. 01, p. 229-250, 1961.

LARISH, L. L. B.; BREWBAKER, J. L. Diallel analyses of temperate and tropical popcorns. Maydica, v. 44, n. 04, p. 279-284, 1999.

MIRANDA, G. V. et al. Genetic variability and heterotic groups of Brazilian popcorn populations. Euphytica, v. 162, n. 02, p. 431-440, 2008.

PINTO, R. J. B. et al. Análise dialélica parcial de linhagens de milho-pipoca. Revista Brasileira de Milho e Sorgo, v. 06, n. 03, p. 323-335, 2007.

PINTO, R. J. B. et al. Análise dialélica de linhagens de milhopipoca. Revista Ceres, v. 54, n. 315, p. 471-477, 2007.

RODRIGUES-ARNON, R.; SCOTT, G. E.; KING, S. B. Maize yield losses caused by southern corn rust. Crop Science, v. 20, n. 03, p. 812-814, 1980.

SANTOS, F. S. et al. Genetic gain prediction of the third recurrent selection cycle in a popcorn population. Acta Scientiarum. Agronomy, v. 30, n. 05, p. 651-655, 2008.

SCAPIM, C. A. et al. Análise dialélica e heterose de populações de milho pipoca. Bragantia, v. 61, n. 03, p. 219-230, 2002.

SCAPIM, C. A. et al. Correlations between the stability and adaptability statistics of popcorn cultivars. Euphytica, v. 174, n. 02, p. 209-218, 2010.
SCHMILDT, E. R. et al. Avaliação de métodos de correção do estande para estimar a produtividade em milho. Pesquisa Agropecuária Brasileira, v. 36, n. 08, p. 10111018, 2001.

SHURTLEFF, M. C. Compendium of Corn Diseases. St. Paul: APS Press, 1992. 105 p.

SILVA, H. P. et al. Capacidade de combinação e heterose para resistência a Puccinia polysora Underw. em milho. Scientia Agricola, v. 58, n. 04, p. 777-783, 2001.

SILVA, T. R. et al. Genetic divergence in popcorn genotypes using microsatellites in bulk genomic DNA. Crop Breeding and Applied Biotechnology, v.09, n. 01, p. 31-36, 2009.

SIMON, G. A. et al. Depressão por endogamia em populações de milho-pipoca. Bragantia, v. 63, n. 01, p. 55-62, 2004.

TRINDADE, A. P. et al. Genetic diversity underlying heterotic groups of popcorn lines of tropical and temperate germplasm determined by SSR markers. Electronic Journal of Biotechonology, v. 13, n. 01, p. 1-9, 2010.

VIEIRA, R. A. et al. Heterotic parametrization for economically important traits in popcorn. Acta Scientiarum. Agronomy, v. 31, n. 03, p. 411-419, 2009a.

VIEIRA et al. Diallel analysis of leaf disease resistance in inbred Brazilian popcorn cultivars. Genetics and Molecular Research, v. 08, n. 04, p. 1427-1436, 2009 b.

VIEIRA, R. A. et al. Resistência de híbridos de milhopipoca a Exserohilum turcicum, agente causal da helmintosporiose do milho. Scientia Agraria, v. 10, n. 05, p. 391-395, 2009c.

ZIEGLER, K. E.; ASHMAN, B. POPCORN. In: Hallauer, A. R. Specialty corns. Boca Raton: CRC Press, 1994. cap. 7, p. 189-223.

ZUMMO, N. Components contributing to partial resistance in maize to Puccinia polysora. Plant Disease, v. 72, n. 02, p. 157-160, 1988. 